\title{
PENGARUH MODEL PEMBELAJARAN KOOPERATIF TIPE THINK PAIR SHARE TERHADAP HASIL BELAJAR SISWA PADA MATA PELAJARAN AKUNTANSI DI SMA LABORATORIUM PERCONTOHAN BANDUNG
}

\author{
Oleh: \\ Muni Anisa \\ (Guru Madrasah Aliyah Cipari) \\ Eka Yulianti \\ (Guru SMA Laboratorium Percontohan)
}

\begin{abstract}
Penelitian ini diawali dari fenomena rendahnya hasil ujian tengah semester di SMA Laboratorium Percontohan. Dari data yang diperoleh dari guru akuntansi maka peneliti melakukan kolaborasi untuk mencari solusi atas permasalahan tersebut. Adapun tujuan dari penelitian ini untuk melihat apakah ada perbedaan hasil belajar siswa kelas eksperimen setelah diberikan treatmen model pembelajaran kooperatif tipe Think Pair Share dengan kelas kontrol yang tidak diberikan treatmen model pembelajaran kooperatif tipe Think Pair Share.

Metode yang digunakan dalam penelitian ini adalah eksperimen dengan desain penelitian Quasi Experimental yang digunakan adalah Nonequivalent Control Group design. Desain ini sama dengan pretest - posttest control group design, hanya pada desain ini kelompok eksperimen maupun kelompok kontrol tidak dipilih secara random. Adapun hasil penelitian antara kelas eksperimen dengan kelas kontrol membuktikan adanya perbedaan peningkatan hasil belajar dikelas eksperimen hasil belajar meningkat sebesar 46.7 sedangkan dikeals kontrol sebesar 25,9. Jelas tenlihat adanya perbedaan hasil belajar yang besar sebesar 20,8.
\end{abstract}

Kata kunci: Model pembelajaran, kooperaif tipe think pair share, hasil belajar.

\section{Pendahuluan}

Saat ini pendidikan menjadi hal utama untuk dilakukan karena dalam pendidikan itu sendiri terdapat nilai-nilai yang baik, luhur, pantas dan indah untuk dikembangkan dalam semua aspek kehidupan dan pendidikan merupakan usaha sadar untuk menumbuhkembangkan potensi sumber daya manusia.

Tujuan pendidikan Nasional pada dasarnya merupakan arti pendidikan yang berlangsung sebagai pendidikan formal, proses pembelajaran berlangsung di sekolah yang menargetkan ukuran keberhasilan untuk setiap jenis pelaksanaan pembelajarannya. Di sekolah menengah tingkat atas atau SMA/MA, pembelajaran tercakup dalam setiap mata pelajaran yang diajarkan, salah satu diantaranya adalah mata pelajaran akuntansi.

Keberhasialan proses pembelajaran dinyatakan dalam bentuk angka atau nilai dan diketahui melalui serangkaian tes formatif dan sumatif yang dilakukan oleh siswa. Untuk proses pendidikan dalam setiap jenjang pendidikan, hasil belajar adalah salah satu ukuran untuk menunjukkan keberhasilan.

Melihat bahwa hasil belajar diukur dari tinggi rendahnya nilai ujian siswa, berikut tabel yang menunjukan nilai UAS yang dilakukan di SMA Laboratorium Percontohan UPI Bandung:

Tabel 1

Nilai tes Akuntansi Kelas XI

\begin{tabular}{|ccc|}
$\begin{array}{c}\text { UAS } \\
\text { Smt1 }\end{array}$ & $\begin{array}{c}\text { Di bawah } \\
\text { KKM }\end{array}$ & $\begin{array}{c}\text { Di atas } \\
\text { KKM }\end{array}$ \\
\hline Kelas Eksperimen & 37 & 0 \\
Kelas Kontrol & 38 & 0
\end{tabular}

(sumber: Nilai UAS Semester 1 Akuntansi kelas XI IPS Laboratorium Percontohan UPI)
Berdasarkan data pada tabel 1 dapat dilihat tidak ada satu orang siswa pun yang mencapai Kriteria Ketuntasan Minimal (KKM). KKM yang ditetapkan oleh sekolah yaitu 70. Oleh karena itu, dapat dikatakan bahwa hasil belajar siswa pada mata pelajaran Akuntansi masih rendah.

Berdasarkan wawancara yang telah dilakukan pada siswa SMA Laboratorium Percontohan UPI Bandung salah satu penyebab rendahnya nilai mata pelajaran akuntansi yang dicapai siswa adalah penyampaian materi atau metode belajar yang selama ini berlangsung kurang menarik. Siswa terlihat kurang antusias, daya kreativitasnya rendah, dan bersikap acuh tak acuh. Penyebabnya mungkin guru kurang menguasai strategi pembelajaran.

Pelajaran akuntansi menurut siswa merupakan pelajaran yang cukup menyibukkan atau menguras pikiran. Pembelajarannya memerlukan ketelitian dan ketekunan cenderung membuat siswa jenuh atau merasa tak memiliki waktu luang untuk sekedar diam. Hal ini tidak terlepas dari metode pembelajarannya yang cenderung serius dan menyita perhatian siswa. Salah satu model pembelajaran yang biasa diterapkan oleh guru dalam kelas adalah pembelajaran konvensional, yang bila tidak dikemas dengan baik tidak akan menarik perhatian siswa, karena cenderung menghafalkan (Darmawan,2002).

Kebiasaan bersikap pasif dalam proses pembelajaran dapat mengakibatkan sebagian besar siswa takut dan malu bertanya pada guru mengenai materi yang kurang dipahami. Suasana belajar di kelas menjadi sangat monoton dan kurang menarik.

Sesuai dengan tuntutan kebutuhan masyarakat dan perkembangan zaman, ilmu 
pengetahuan dan teknologi yang semakin pesat, disinilah tugas guru akuntansi untuk senantiasa meningkatkan keterampilan dan kualitas intelektual di dalam kegiatan pembelajaran. Guru akuntansi perlu tampil disetiap kesempatan baik sebagai pendidik, pengajar, pelatih, inovator, fasilisator maupun sebagai dinamisator dengan cara menerapkan model pembelajaran supaya tercipta proses pembelajaran yang aktif, inovatif, kreatif, efektif, dan menyenangkan.

Terdapat beberapa faktor yang berpengaruh terhadap hasil belajar siswa di sekolah, baik faktor yang ada dalam diri siswa yang meliputi motivasi, minat, persepsi siswa terhadap guru, kepuasan siswa dalam proses belajar mengajar, sikap maupun kondisi fisik dan psikis siswa. Selain itu terdapat pula faktor eksternal yang ada di luar diri siswa yang meliputi kompetensi guru, strategi mengajar guru, kurikulum, keluarga, lingkungan dan fasilitas belajar.

Slameto mengungkapkan (2003:180) ada beberapa faktor yang diduga dapat mempengaruhi hasil belajar, diantaranya:

a. Kurangnya motivasi belajar siswa

b. Tidak adanya minat dan bakat

c. Model atau metode belajar kurang baik dan efektif

d. Media yang digunakan masih kurang baik

Dalam proses pembelajaran di sekolah, permasalahan yang dihadapi antara lain: penggunaan metode mengajar yang kurang tepat akan turut menentukan efektivitas dan efisiensi proses belajar mengajar. Dengan penggunaan metode belajar yang tepat, guru diharapkan mampu memotivasi siswa agar lebih semangat dalam belajar dan membimbing mereka berpikir kritis.

Pemilihan model dan metode pembelajaran yang sesuai dengan tujuan kurikulum dan potensi siswa merupakan kemampuan dan keterampilan dasar yang harus dimiliki oleh seorang guru. Ketepatan guru dalam memilih model dan metode pembelajaran akan berpengaruh terhadap keberhasilan siswa.

Untuk meningkatkan hasil belajar siswa, guru dapat memilih dan menerapkan model pembelajaran yang lebih efektif, salah satunya adalah model pembelajaran kooperatif. Menurut Anita Lie, ada berbagai teknik yang bisa dilakukan guru dalam pelaksanaan model pembelajaran kooperatif (2005: 55-73) seperti: Think Pair Share, Numbered Heads Together (NHT), Jigsaw, Two Stay Two Stray, Berkirim Salam dan Soal, Inside Outside Circle, Kancing Gemerincing, Berpikir-BerpasanganBerempat dan lain-lain.

Dalam penelitian ini, dipilih model pembelajaran Think-Pair-Share karena model pembelajaran ini memberi kesempatan pada siswa untuk berpikir, menjawab, dan saling membantu satu sama lain dan akan menambah variasi model pembelajaran yang lebih menarik, menyenangkan, meningkatkan aktivitas dan kerja sama siswa. Pembelajaran kooperatif dengan model Think-Pair-Share ini mudah diterapkan pada semua mata pelajaran termasuk Akuntansi (Anita Lie, 200:48).
Tipe ini terdiri dari tiga tahapan, yaitu think (berpikir secara individu), pair (berpasangan dengan teman sebangku) berkaitan dengan proses pengecekan kebenaran proses akuntansi yang terjadi, dan share (berbagi jawaban dengan pasangan lain/ seluruh kelas).

Berdasarkan penomena dan teori-teori di atas, peneliti ingin mengetahui sejauh mana model pembelajaran kooperatif tipe Think Pair Share dapat meningkatkan hasil belajar siswa pada mata pelajaran akuntansi di SMA Laboratorium Percontohan UPI Bandung.

Berdasarkan latar belakang masalah yang telah diungkapkan di atas, maka rumusan masalah dalam penelitian ini bagaimana perbedaan hasil belajar siswa kelas experimen yang menggunakan model pembelajaran kooperatif tipe Think Pair Share dengan hasil belajar siswa kelas kontrol yang tidak menggunakan model pembelajaran kooperatif tipe Think Pair Share.

\section{Landasan Teori}

Dalam keseluruhan proses pengajaran di sekolah, proses belajar mengajar merupakan kegiatan yang paling pokok karena disanalah terdapat interaksi yang dilaksanakan antara siswa sebagai pelajar dan guru sebagai pengajar untuk mencapai tujuan yang telah ditentukan. Proses belajar mengajar yang telah dilaksanakan tersebut akan menghasilkan prestasi belajar yang dicapai oleh siswa. Berbicara tentang prestasi belajar tidak terlepas dari pengertian belajar. Berbagai pendapat dari para ahli tentang definisi belajar banyak dikemukakan, sehingga dapat diartikan belajar adalah usaha yang dilakukan siswa untuk memperoleh suatu perubahan tingkah laku yang baru, secara sengaja, disadari dan berkesinambungan. Keberhasilan belajar siswa dalam proses belajar mengajar dapat diukur dari tinggi rendahnya prestasi belajar yang dicapai oleh siswa itu sendiri.

Pada dasarnya prestasi belajar merupakan perubahan perilaku yang mencakup aspek kognitif, afektif dan psikomotorik sebagai akibat dari proses belajar mengajar yang telah dilaksanakan dan dapat diukur berdasarkan kriteria dan standar yang telah ditetapkan. Prestasi belajar tidak terlepas dari faktor yang mempengaruhinya baik faktor internal (faktor yang berasal dari dalam diri individu itu sendiri) maupun faktor eksternal (faktor yang berasal dari luar individu).

Faktor-faktor tersebut saling berinteraksi secara langsung maupun tidak langsung dan mempengaruhi prestasi belajar siswa. Dalam Taksonomi Bloom yang diutarakan dua faktor utama yang dominan terhadap hasil belajar yaitu pertama adalah karakteristik siswa (kemampuan, minat, hasil belajar sebelumnya, motivasi) dan yang kedua adalah karakteristik pengajaran (guru, metode pengajaran, fasilitas belajar).

Salah satu faktor yang mempengaruhi prestasi belajar adalah pendekatan belajar yang meliputi strategi dan metode pembelajaran yang dirangkum dalam model pembelajaran 
Model pembelajaran merupakan suatu set prosedur dan materi yang memiliki fungsi sebagai kerangka dan arah bagi guru dalam melakukan proses pembelajaran. Dalam proses pembelajaran guru diharuskan dapat memahami tentang model pembelajaran efektif yang dapat membantu siswa agar dapat belajar secara optimal dan mampu meningkatkan keaktifan siswa dalam proses pembelajaran.

Model Pembelajaran Think Pair Share sangat cocok diterapkan dalam mata pelajaran akuntansi karena akuntansi merupakan mata pelajaran yang menekankan pada pemahaman konsep dan keterampilan vokasional, sedangkan Think Pair Share sendiri mengarahkan siswa untuk memiliki pemahaman konsep dan keterampilan .

Dalam proses pembelajaran, model pembelajaran kooperatif tipe Think Pair Share tidak sama dengan sekedar belajar dalam kelompok. Ada unsur-unsur dasar dalam model pembelajaran kooperatif yang membedakannya dengan pembagian kelompok yang dilakukan seperti biasanya. Hal ini nantinya, akan berpengaruh terhadap pencapaian tujuan yang telah ditetapkan oleh guru, salah satunya adalah pencapaian prestasi belajar siswa yang optimal.

Berdasarkan penjelasan di atas, hasil belajar dapat dipengaruhi oleh beberapa faktor diantaranya penggunaan model pembelajaran. Salah satu tipe dari pembelajaran yang dianggap efektif oleh penulis dalam pembelajaran akuntansi adalah pembelajaran kooperatif tipe Think Pair share.

Bertitik tolak dari kerangka pemikiran, maka penulis berpendapat bahwa model pembelajaran kooperatif tipe Think Pair Share dapat meningkatkan hasil belajar siswa. Dengan demikian, hipotesis dalam penelitian ini adalah: "Ada perbedaan hasil belajar siswa kelas experimen yang menggunakan model pembelajaran kooperatif tipe Think Pair Share dengan hasil belajar siswa kelas kontrol yang tidak menggunakan model pembelajaran kooperatif tipe Think Pair Share".

\section{Metode Penelitian}

Metode penelitian yang digunakan daiam penelitian ini adalah metode eksperimen." Penelitian eksperimen diartikan sebagai metode penelitian yang digunakan untuk mencari pengaruh perlakuan tertentu terhadap yang lain dalam kondisi yang terkendalikan". (Sugiyono 2008 : 72 ). Alasan peneliti memilih metode ini adalah karena peneliti ingin mengetahui bagaimana pengaruh model pembelajaran kooperatif tipe Think Pair Share terhadap hasil belajar siswa.

Sedangkan desain penelitian yang digunakan adalah Quasi Experimental Design. Desain ini merupakan pengembangan dari True Experimental Design. Quasi Experimental design digunakan karena pada kenyataannya sulit mendapatkan kelompok kontrol yang digunakan untuk penelitian.

Adapun bentuk desain Quasi Experimental yang digunakan adalah Nonequivalent Control Group design. Desain ini sama dengan pretest - posttest control group design.

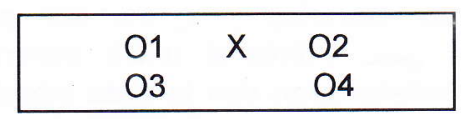

( Sugiyono $2008: 79$ )

Dalam penelitin ini terdapat kelompok eksperimen dan kelompok kontrol yang keduanya diberikan tes ( 01 dan 03 ) untuk mengetahui keadaan awal adakah perbedaan antara keduanya. Selanjutnya kelompok eksperimen diberi perlakuan pembelajaran Cooperative Leaming tipe Think Pair Share ( 02 ) sementara kelompok kontrol tidak diberi perlakuan, yaitu pembelajaran tidak diberikan perlakuan dengan penggunaaan model pembelajaran ( 04 ). Kemudian kelompok eksperimen dan kelompok kontrol diberi pos-test untuk melihat perbedaannya apakah ada peningkatan hasil belajar setelah diberikan treatment.

Penelitian ini merupakan penelitian yang ingin melihat pengaruh dari suatu treatment. Suatu objek penelitian diberi perlakuan (treatment) kemudian diperbandingkan dampaknya antara siswa yang diberi treatment dengan yang tidak diberi treatmen. Berikut operasionalisasi variabel penelitian:

Tabel 2

Operasionalisasi Variabel

\begin{tabular}{|lll|}
\hline \multicolumn{1}{c}{ Variabel } & Indikator & Skala \\
\hline Hasil Belajar Siswa & Nilai rata- & Interval \\
dengan menggunakan & rata tes & \\
model pembelajaran & formatif & \\
kooperatif tipe Think Pair & setelah & \\
Share & treatmen & \\
\hline
\end{tabular}

Hasil belajar siswa yang Nilai rata- Interval tidak menggunakan model rata tes pembelajaran cooperatif formatif tife Think Pair Share.

Penelitian ini dilaksanakan di SMA Laboratorium Percontohan UPI Bandung, maka yang menjadi populasi penelitian ini adalah kelas XI IPS SMA Laboratorium Percontohan UPI Bandung . Sampel yang digunakan adalah sampel jenuh yaitu teknik penentuan sampel bila semua anggota populasi digunakan sebagai sampel. Sampel dalam penelitian ini adalah kelas XI IPS B sebanyak 37 orang sebagai kelompok eksperimen dan kelas XI IPS A sebanyak 38 orang sebagai kelompok kontrol.

Data penelitian dikumpulkan melalui teknik tes tertulis yang dilakukan untuk mengungkapakan hasil belajar siswa. Tes dilakukan dua kali yaitu sebelun (pre-test) dan sesudah (post-test) penerapan treatment.

Penelitian ini dilaksanakan dalam empat tahap; yaitu tahap persiapan, tahap penerapan, tahap analisis data dan tahap penarikan kesimpulan. Untuk lebih jelasnya setiap tahap akan dijelaskan sebagai berikut: 
a. Tahap persiapan

Dalam tahap ini peneliti melakukan studi pustaka, studi kurikulum, dan menentukan sampel penelitian. Setelah sampel penelitian ditentukan, kemudian peneliti menentukan kelas kontrol dan kelas eksperimen lalu membuat kelengkapan instrument penelitian seperti; tes, rencana pelaksanaan pembelajaran, format observasi siswa dan guru. Sebelum tes di ujikan, terlebih dahulu di lakukan uji validitas, reliabilitas, taraf kesukaran dan daya pembeda soal.

b. Tahap Penerapan penerapaan model pembelajaran kooperatif tipe Think Pair Share dilaksanakan selama 3 bulan. Dari tangaal 10 januari- 8 April 2011. Setelah model pembelajaran kooperatif tipe Think Pair Share diterapkan, selanjutnya di adakan tes dengan tujuan untuk melihat tingkat pemahaman siswa akan materi pelajaran yang diajarkan dengan mengunakan model pembelajaran kooperatif tipe Think Pair Share.

c. Tahap Analisis Data

Dalam penelitian ini, data yang di analisis adalah data tes setelah treatment dilaksanakan. Soal yang digunakan dalam test berjumlah 16 soal yang terdiri dari materi jurnal penyesuaian, kertas kerja, dan laporan keungan. Sebelum soal diujikan, terlebih dahulu dilakukan pengujian kelayakan instrument penelitian.

d. Tahap Pengambilan Kesimpulan

Pada tahap ini, kegiatan yang dilakukan adalah membuat kesimpulan yang berdasarkan atas hasil analisis data yang telah di dapatkan

Data penelitian dikumpulkan melalui teknik tes tertulis yang dilakukan untuk mengungkapakan hasil belajar siswa. Tes dilakukan dua kali yaitu sebelun (pre-test) dan sesudah (post-test) penerapan treatment.Untuk mengetahui apakah tes tertulis yang digunakan sebagai instrument dalam penelitian ini mampu menberikan data yang valid dan reliabel, maka dilakukan serangkaian uji instrument, uji validitas soal dan uji reliabilitas soal.

Sebelum menguji hipotesis diterima atau tidak, terlebih dahulu dilakukan uji normalitas, hal ini dilakukan untuk melihat bahwa data yang diperoleh dari skor tes, baik kelompok kontrol maupun kelompok eksperimen berdistribusi normal atau tidak. Untuk menguji normalitas tes tersebut digunakan uji chi kuadrat $\left(x^{2}\right)$.

Bila data berdistribusi normal, maka langkah selanjutnya adalah melihat perbedaan nilai akuntansi antara siswa yang menggunakan model pembelajaran kooperatif tipe Think Pair Share dengan nilai siswa yang tidak menggunakan model pembelajaran kooperatif tipe Think Pair Share melalui uji-t, langkah-langkahnya adalah sebagai berikut: a. Menentukan formulasi hipotesis

b. Menentukan taraf nyata $\alpha$ dan t tabel

c. Menentukan nilai uji statistik yaitu dengan mencari t hitung

Perumusan hipotesis statistiknya adalah:

$\mathrm{H}_{0} \quad$ : Tidak terdapat perbedaan hasi antara siswa yang menggunakan model pembelajaran kooperatif tipe Think Pair Share dengan siswa yang tidak menggunakan model pembelajaran kooperatif tipe Think P air Share

$\mathrm{H}_{1}$ : Terdapat perbedaan hasil belajar antara siswa yang menggunakan model pembelajaran kooperatif tipe Think Pair Share dengan siswa yang tidak menggunakan model pembelajaran kooperatif tipe Think Pair Share

$\mathrm{H}_{0}=\mathrm{t}_{\text {hitung }}<\mathrm{t}_{\text {tabel }}$

$\mathrm{H}_{1}=\mathrm{t}_{\text {hitung }} \geq \mathrm{t}_{\text {tabe }}$

(Suharsimi Arikunto $2006: 312$ )

\section{Hasil Penelitian dan Pembahasan}

a. Data Hasil Post- Tes Pada Kelas Kontrol

Setelah pembelajaran dengan tidak menerapkan model pembelajaran maka diadakan post-test dengan tujuan untuk melihat hasil belajar siswa. Dari penelitian yang telah dilakukan maka didapatkan hasil tes sebagai berikut:

Tabel 3

Rata-rata Hasil Post-Tes Siswa

\begin{tabular}{|c|c|}
\hline Interval & Frekuensi \\
\hline $47-56$ & 3 \\
\hline $57-66$ & 10 \\
\hline $67-76$ & 11 \\
\hline $77-86$ & 10 \\
\hline $87-96$ & 3 \\
\hline $97-100$ & 1 \\
\hline
\end{tabular}

(sumber: data diolah)

Dari tabel 3 dijelaskan tiga orang siswa $(7,9 \%)$ memiliki nilai yang berada pada rentang 47 56 , sembilan orang siswa $(23,9 \%)$ memiliki nilai yang berada pada rentang 57-66, 12 orang siswa $(31,5 \%)$ memiliki nilai pada rentang $67-76$, pada rentang $77-86$ sebanyak 10 orang siswa $(26,3 \%)$ yang memperolehnya, kemudian pada rentang $87-$ 96 sebanyak tiga orang siswa $(7,9 \%)$, dan terakhir pada rentang 97-100 sebanyak satu orang siswa $(2,6 \%)$.

Melihat hasil tes pada kelas kontrol, maka kemampuan siswa dapat dibagi kedalam tiga kategori, yaitu:

Tabel 4

Tingkat Kemampuan Siswa

\begin{tabular}{cc} 
Kategori & Jumlah \\
\hline Tinggi & 4 \\
Sedang & 22 \\
Rendah & 12
\end{tabular}

(Sumber: data diolah) 


\section{b. Gambaran Penerapan Model Pembelajaran Kooperatif tipe Think Pair Share}

Dalam penelitian ini yang menjadi treatment adalah model pembelajaran kooperatif tipe Think Pair Share, adapun kegiatan-kegiatan yang dilakukan pada saat penelitian adalah seagai berikut:

1) Pada hari pertama, peneliti melihat kondisi awal siswa sebelum pembelajaran dimulai kemudian peneliti juga menyampaikan sedikit gambaran kepada siswa mengenai materi akuntansi jurnal penyesuaian.

2) Pada pertemuan selanjutnya, peneliti membagi siswa menjadi beberapa kelompok. Dari pembagian kelompok didapatkan delapan kelompok dengan masing-masing kelompok memiliki empat anggota dengan tingkat kemampuan siswa yang hetorogen . Kemudian guru menyajikan permasalahan yang berkaitan dengan materi yang disampaikan dalam bentuk soal tertulis dan membagikannya pada masing-masing kelompok. Dari soal yang telah diberikan, siswa disuruh memikirkan dahulu jawabannya (Think) setelah itu selanjutnya siswa mengerjakan dan menuliskan jawaban pada lembar jawaban sendiri tanpa bertanya pada teman satu kelompok. Setelah selesai mengerjakan baru siswa dianjurkan untuk berpasangan dengan teman satu kelompok untuk bertukar pendapat guna mengambil kesimpulan sementara (Pair). Setelah di dapat kesimpulan sementara dari setiap kelompok diminta untuk presentasi di depan kelas(Share).

3) Pengidentifikasian secara berkelompok bertujuan untuk meningkatkan pemahaman siswa atas setiap soal yang telah diberikan, sehingga setiap siswa mampu mempresentasikan hasil diskusi kelompoknya di depan kelas.

4) Setelah siswa selesai melakukan identifikasi, kemudian setiap kelompok menuliskan jawaban kelompok dalam lembar jawaban yang berbeda. Pada tahap selanjutnya, beberapa perwakilan kelompok mempersentasikan hasil diskusinya di depan kelas untuk di diskusikan kembali oleh seluruh kelompok dalam kelas sampai menemukan jawaban bersama hasil pemikiran bersama.

5) Setelah model pembelajaran kooperatif learning di terapkan, untuk melihat perubahan nilai hasil belajar siswa. maka peniliti melakukan tes.

D. Data Hasil Post-Tes Pada Kelas
Eksperimen
Data untuk kelas eksperimen diperoleh dari hasil tes setelah diadakannya pembelajaran dengan menggunakan model pembelajaran kooperatif tipe Think Pair Share. Hasil tes siswa pada kelas eksperimen dijabarkan dalam tabel 5 berikut ini:
Tabel 5

Rata-rata Hasil Post-Tes Siswa

\begin{tabular}{|c|c|}
\hline Interval & Frekuensi \\
\hline $47-55$ & 3 \\
\hline $56-64$ & 3 \\
\hline $65-73$ & 6 \\
\hline $74-82$ & 17 \\
\hline $83-91$ & 7 \\
\hline $92-100$ & 1 \\
\hline \multicolumn{2}{|c|}{ (sumber: data diolah) } \\
\hline
\end{tabular}

Dari tabel 5 dapat dilihat nilai hasil tes siswa di atas, dapat dijelaskan tiga orang siswa $(8,1 \%)$ memiliki nilai yang berada pada rentang $47-55$, tiga orang siswa $(8,1 \%)$ memiliki nilai yang berada pada rentang 56-64, lima orang siswa $(5,4 \%)$ memiliki nilai pada rentang 65-73, pada rentang 74-82 merupakan jumlah terbanyak yaitu 17 orang $(13,5 \%)$, kemudian pada rentang 83-91 dengan jumlah tujuh orang siswa $(43,2 \%)$ yang memperolehnya, dan terakhir pada rentang 92-100 sebanyak satu orang siswa $(21,6 \%)$

Hasil di atas menjelaskan, adanya rata-rata peningkatan hasil belajar siswa setelah diterapkannya model pembelajaran kooperatif tipe Think Pair Share. Dari 37 orang siswa yang mengikuti pos-test, sebanyak 31 orang siswa (84\%) memperoleh rata-rata nilai di atas KKM yang telah ditetapkan.

Melihat hasil tes dari kelas eksperimen di atas, kemampuan siswa dapat dibagi ke dalam tiga kategori yaitu:

Tabel 6

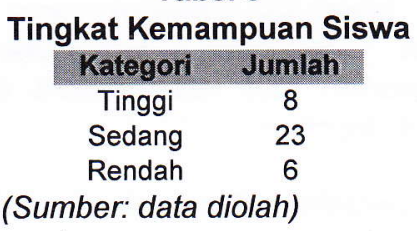

C. Perbandingan Hasil Belajar Kelas
Eksperimen dengan Kelas Kontrol Perbandingan yang dimaksud disini adalah perbandingan rata-rata (mean) antara kelas eksperimen dengan kelas kontrol. Telah disebutkan pada bagian sebelumnya bahwa rata-rata Post-test kelas eksperimen adalah 76,2 sedangkan kelas kontrol memiliki nilai rata-rata tes sebesar 72,2 . Perbedaan yang terjadi diwujudkan dalam bentuk gambar berikut ini:

\section{Grafik 1 \\ Perbandingan Hasil Belajar Kelas Eksperimen dan Kelas Kontrol}

Rata-rata Hasil Post-Tes

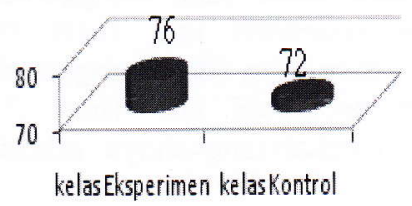


Sebelum memulai menganalisis data penelitian, ada satu pekerjaan penting yang tidak boleh diabaikan yang menjadi prasyarat yang harus dipenuhi sebelum pelaksanaan analisis data. Pekerjaan yang dimaksud adalah pengujian penyebaran data, apakah data tersebut tersebar antara nilai paling tinggi dengan nilai paling rendah, serta variabilitas di dalamnya.

Pengujian normalitas data tes kelas eksperimen dan kelas kontrol menggunakan uji chi kuadrat $\left(\chi^{2}\right)$. Pengujian di kedua kelas ini dilakukan pada $\alpha=0,05$ dengan derajat kebebasan $\mathrm{dk}=\mathrm{k}-1=6-1=5$. Dengan demikian, $\chi^{2}$ tabel untuk tes kedua kelas adalah 11,070.
Kelas eksperimen memiliki $\chi^{2}$ nitung sebesar 10,6 apabila dibandingkan dengan $\chi^{2}$ tabel , maka diketahui $\chi^{2}$ nitung $<\chi^{2}$ tabel, yang berarti bahwa data dinyatakan berdistribusi normal. Untuk kelas kontrol, memiliki $\chi^{2}$ hitung sebesar 4,223 apabila dibandingkan dengan $\chi^{2}$ tabel, maka diketahui $\chi^{2}$ hitung $<\chi^{2}$ tabel, maka data tes dinyatakan berdistribusi normal. Penghitungan normalitas tes kedua kelas ini dapat dilihat dalam lampiran. Tabel berikut ini merupakan hasil uji normalitas kedua kelas:

Tabel 7

Uji Normalitas Tes Kelas Eksperimen dan Kelas Kontrol

\begin{tabular}{lccc}
\multicolumn{1}{c}{ Kelas } & $\chi^{2}$ hilung & $\chi^{2}$ tabel & \multicolumn{1}{c}{ Kriteria } \\
\hline Eksperimen & 10,6 & 11,070 & Berdistribusi Normal \\
Kontrol & 9,77 & 11,070 & Berdistribusi Normal
\end{tabular}

Setelah semua data penelitian berdistribusi normal, maka langkah berikutnya adalah menguji hipotesis. Langkah-langkah untuk melakukan pengujian hipotesis dijabarkan sebagai berikut:

- Menentukan taraf kepercayaan dan t tabel Taraf kepercayaan dalam penelitian ini ditetapkan sebesar 95\%, atau $\alpha=0,05$ sedangkan nilai $\mathrm{dk}$ untuk penelitian ini adalah $37+38-2=73$ maka nilai $t$ tabel untuk $\mathrm{dk} 73$, dengan taraf signifikansi 0,05 adalah $\underline{1,9930}$

- Menentukan nilai uji statistik yaitu dengan mencari t hitung

Setelah dilakukan perhitungan melalui tabulasi ( perhitungan lengkap pada lampiran ) maka diperoleh data sebagai berikut :

(a) Untuk kelas eksperimen, rata-rata tes adalah sebagai berikut :

$\mathrm{M}_{\mathrm{x}}=7.423,57$

(b) Untuk kelas kontrol, rata-rata tes adalah sebagai berikut:

$\mathrm{M}_{\mathrm{y}}=9.544$

Dari perhitungan di atas diperoleh nilai $t$ hitung sebesar 6,3817 sedangkan $t$ tabel sebesar 1,9930 maka berlaku ketentuan bila $t$ hitung lebih besar daripada $\mathrm{t}$ tabel, maka $\mathrm{H}_{0}$ ditolak dan $\mathrm{H}_{1}$ diterima. Kesimpulannya adalah terdapat perbedaan prestasi belajar antara siswa kelas XI IPS yang belajar menggunakan model pembelajaran kooperatif tipe Think Pair Share dengan siswa XI IPS yang belajar menggunakan model pembelajaran Konvensional. Artinya hasil belajar siswa yang menggunakan model pembelajaran kooperatif tipe hink Pair Share berbeda dengan hasil belajar siswa yang tidak menggunakan model pembelajaran kooperatif tipe thik pair Share. Dengan demikian, maka model pembelajaran kooperatif tipe Think Pair Share baik digunakan dalam pembelajaran akuntansi.
Berdasarkan data penelitian yang ada, kelas eksperimen dan kelas kontrol mempunyai rata-rata hasil Pree-Test yang berbeda. Rata-rata nilai Pree-Test kelas eksperimen adalah 29,5 sedangkan rata-rata Pree-Test kelas kontrol adalah 46,3 . jika dibandingkan dari hasil rata-rata ini, maka kelas kontrol memiliki rata-rata skor yang lebih tinggi daripada kelas eksperimen. Berikut tabel yang menunjukan rata-rata test kelas eksperimen dan kelas kontrol:

Tabel 8

\begin{tabular}{|c|c|c|}
\hline \multicolumn{3}{|c|}{$\begin{array}{c}\text { Perbandingan Perubahan Hasil Belajar Kelas } \\
\text { Eksperimen dan Kelas Kontrol }\end{array}$} \\
\hline Kelas & Pree-test & Pos-test \\
\hline Eksperimen & 29,5 & 76,2 \\
\hline Kontrol & 46,3 & 72,2 \\
\hline
\end{tabular}

Dalam proses pembelajaran, kelas ekperimen memperoleh treatment berupa pembelajaran kooperatif tipe Think Pair Share dan kelas kontrol belajar seperti biasa dan selanjutnya pelaksanaan post-tes. Berdasarkan data hasil penelitian, kelas eksperimen diperoleh data skor rata-rata post-test sebesar 76,2 dari rata-rata hasilpre-test 29,5 sementara untuk kelas kontrol ratarata post-test 72,2 dari rata-rata nilai pre-test 46,3 . Artinya kelas eksperimen memperoleh peningkatan hasil belajar jauh lebih tinggi dari kelas kontrol.Kelas eksperimen meningkat sebesar 46,7 sementara kelaas kontrol hanya meningkat sebesar 25,9.

Dilihat dari rata-rata post-tes pada kedua kelas, menunjukkan bahwa hasil belajar siswa yang menggunakan model pembelajaran kooperatif tipe Think-Pair-Share lebih baik dibandingkan dengan siswa yang tidak menggunakan model pembelajaran. 
Hasil ini menunjukkan bahwa model pembelajaran kooperatif tipe Think-Pair-Share dapat dijadikan salah satu alternatif dalam pembelajaran akuntansi karena dapat meningkatkan hasil belajar siswa terhadap mata pelajaran akuntansi pada materi jurnal penyesuaian dan laporan keuangan. Penggunaan model pembelajaran kooperatif tipe Think-Pair-Share ternyata menghasilkan hasil belajar yang lebih baik dibandingkan dengan kelas yang tidak menggunakan model pembelajaran. Hal ini dikarenakan model pembelajaran koopertif tipe Think-Pair-Share menerapkan struktur kelompok kecil (berpasangan) yang memiliki tiga tahapan pembelajaran utama, yaitu: think (berpikir), pair (berpasangan), dan share (berbagi).

Tahapan pertama yaitu think (berpikir) dimana guru mengajukan permasalahan atau pertanyaan kepada siswa kemudian meminta siswa untuk memikirkan jawaban (penyelesaian) dari permasalahan tersebut. Kegiatan selanjutnya yaitu pair (berpasangan) artinya siswa diminta berpasangan untuk mendiskusikan jawaban yang paling tepat dari permasalahan yang telah disampaikan guru ataupun pengembangan dari permasalahan pertama. Kegiatan yang ketiga yaitu share dimana siswa berbagi jawaban kelompoknya dengan seluruh kelas. Oleh karena itulah pembelajaran dengan model Think-Pair-Share unggul dalam hasil belajar berupa aspek kognitif, afektif, dan psikomotorik, akan tetapi hasil belajar yang diteliti dalam penelitian ini hanyalah hasil belajar kognitif.

Penelitian mengenai penggunaan model pembelajaran kooperatif tipe Think Pair Share pada mata pelajaran akuntansi bukan merupakan hal baru dalam lingkungan program studi pendidikan akuntansi UPI. Penelitian tentang model pembelajaran kooperatif yang ada sebelumnya, seperti: penelitian "Pengaruh Penggunaan Model Pembelajaran Kooperatif tipe Think Pair Share terhadap hasil belajar siswa pada mata pelajaran akuntansi" oleh Nunur Nurlaela dan "Pengaruh Penggunaan Metode Cooperative Learning Terhadap Hasil Belajar Siswa dalam Mata Pelajaran Akuntansi" oleh Ganda Setiawan. Keduanya menyimpulkan bahwa pembelajarn kooperatif dapat meningkatkan hasil belajar siswa. Hal ini sesuai dengan yang dikemukakan oleh Thompson (dalam Eti Sumartini, 2007:74) bahwa 'pembelajaran kooperatif mempunyai manfaat untuk meningkatkan hasil belajar, meningkatkan motivasi dan memperdalam pemahaman' dan ini sesuai dengan karakteristik pelajaran akuntansi.

Hasil pengujian pendistribusian data skor tes kelas eksperimen dan kelas kontrol berdistribusi normal, sehingga dapat disimpulkan data penelitian yang diperoleh dalam penelitian ini sudah layak untuk dianalisis karena telah sesuai dengan aturan yang berlaku dalam penelitian.

Dari pengujian hipotesis, menghasilkan pernyataan bahwa hipotesis yang diajukan oleh peneliti atau hipotesis alternatif $\left(\mathrm{H}_{1}\right)$ dinyatakan diterima dan $\mathrm{H}_{0}$ ditolak. Oleh karena itu, peneliti memiliki pendapat bahwa hasil belajar siswa XI IPS B yang menjadi kelas eksperimen berbeda dengan hasil belajar kelas XI IPS A sebagai kelas kontrol dalam penelitian ini.

Diterimanya hipotesis menunjukkan bahwa penerapan model pembelajaran kooperatif tipe Think Pair Share berpengaruh dalam upaya peningkatan hasil belajar siswa, karena bila dilihat dari perbandingan hasil tes antara kelas eksperimen dengan kelas kontrol menunjukkan nilai rata-rata kelas eksperimen lebih tinggi dibandingkan dengan kelas kontrol.

Karena terdapat perbedaan hasil belajar antara kelas eksperimen dengan kelas kontrol, maka peneliti mencoba menganalisis latar belakang timbulnya kondisi ini. Proses ini diawali mencoba mencari tahu kondisi akademik siswa. Kondisi akademik ini berkaitan dengan kondisi kognitif siswa, sebagaimana yang dikemukakan oleh Muhibbin Syah (2005:106) bahwa proses pembelajaran dipengaruhi oleh faktor internal siswa seperti jasmaniah, psikologis (kognitif dan afektif). Dengan demikian, dapat ditarik kesimpulan bahwa model pembelajaran kooperatif tipe Think Pair Share mampu meningkatkan hasil belajar siswa dalam mata pelajaran akuntansi pada materi jurnal penyesuaian dan laporan keuangan. Oleh karena itu, model pembelajaran kooperatif tipe Think Pair Share baik digunakan pada materi jurnal penyesuaian dan laporan keuangan dalam pelajaran akuntansi.

\section{Simpulan dan Saran}

Berdasarkan hasil penelitian pada pembahasan sebelumnya, ditarik kesimpulan Terdapat perbedaan hasil belajar antara siswa yang belajar menggunakan model pembelajaran kooperatif tipe Think Pair Share (kelas eksperimen) dengan siswa yang tidak menggunakan model pembelajaran Kooperatif tope Think Pair Share (kelas kontrol). Berdasarkan kesimpulan tersebut, penulis menyarankan bahwa Model Pembelajaran Kooperatif tipe Think Pair Share dalam proses pembelajaran dapat meningkatkan hasil belajar siswa, dan sebaiknya dijadikan sebagai salah satu alternatif dalam kegiatan pembelajaran akuntansi khususnya materi jurnal penyesuaian dan laporan keuangan. Selanjutnya disarankan kepada para guru untuk meneliti Model Pembelajaran Kooperatif tipe Think Pair Share pada materi Akuntansi lainnya atau menggunakan tipe lain dengan model pembelajaran kooperatif.

\section{DAFTAR PUSTAKA}

Abin Syamsuddin. (2005). Psikologi Kependidikan. Bandung: PT Remaja Rosda Karya.

Amin Suyitno. 2003. Dasar-Dasar Proses Pembelajaran Matematika 2. Semarang : Jurusan Matematika FMIPA UNNES.

Anita Lie. (2005). Cooperative Learning, Mempraktikan Cooperative Learning di Ruang-Ruang Kelas. Jakarta: Grasindo

Djamarah, SB. dan Zain, S. (2002). Strategi Belajar Mengajar. Jakarta: Rineka Cipta. 
Etin Solihatin, dkk. 2007. Cooperative Leaming Analisis Model Pembelajaran IPS. Jakarta : Bumi Aksara.

Isjoni. (2007). Cooperative leaming. Bandung:Alfabeta

Kardiman, dkk. (2009). Prindsip-Prinsip Akuntansi 2 SMA kelas XII. Jakarta: Yudhistira.

M. D. Dahlan. (1997). Faktor-faktor yang Mempengaruhi Prestasi Belajar. Jakarta : Rajawali

Muhibbin Syah. (1995). Psikologi Pendidikan. Bandung: Grafindo Persada. (2007). Psikologi Pendidikan dengan Pendekatan Baru. Bandung: Remaja Rosda Karya.

Mulyono Abdurrahman. (2003). Pendidikan Anak bagi Anaka Berkesulitan Belajar. Jakarta: Rineka Cipta.

Nana Syaodih Sukmadinata. (2005). Landasan Psikologi Proses Pendidikan. Bandung: Rosda Karya.

Rahmat Moeslihat. (2005). Akuntansi untuk SMA Kelas XI. Bogor : CV. Regina.

Riduwan. (2005). Dasar-Dasar Statistika. Bandung: Alfabeta.

Slameto. (2003). Belajar dan Faktor-Faktor yang Mempengaruhinya. Jakarta: PT. Rineka Cipta
Slavin, Robert.E. (2009). COOPERATIVE LEARNING Teori, Riset dan Praktik. Bandung : Nusa Media

Solihatin dan Raharjo. (2008). Cooperative Learning, Analisis Model Pembelajaran IPS. Jakarta: Bumi Aksara

Sudjana. (2004). STATISTIKA untuk Ekonomi dan Niaga II. Bandung: PT Tarsito.

Suharsimi Arikunto. (2006). Prosedur Penelitian Suatu Pendekatan Praktek. Jakarta: PT. Rineka Cipta (2008). Dasar-Dasar Evaluasi Pendidikan (Edisi Revisi). Jakarta: Bumi Aksara

Sugiyono. (2006). Metode Penenlitian Bisnis. Bandung: Alfabeta

(2007). Statistika untuk Penelitian. Bandung: Alfabeta

Tim Dosen Program Studi Pendidikan Akuntansi. (2009). Pedoman Operasional Penulisan Skripsi. Bandung: Program studi Pendidikan Akuntansi.

Trianto. (2007). Model-Model Pembelajaran Inovatif Berorientasi Konstruktivistik. Jakarta: Prestasi Pustaka Publisher

Uzer Usman. (2009). Menjadi Guru Profesional. Bandung: PT Remaja Rosdakarya.

Undang-Undang Sistem Pendidikan Nasional No. 20 tahun 2003

http://Andreasviklund.WordPress.com 